\title{
The determinants of pharmaceutical R\&D expenditures: evidence from Japan
}

Citation for published version (APA):

Mahlich, J. C., \& Roediger-Schluga, T. (2006). The determinants of pharmaceutical R\&D expenditures: evidence from Japan. UNU-MERIT, Maastricht Economic and Social Research and Training Centre on Innovation and Technology. UNU-MERIT Working Papers No. 015

Document status and date:

Published: 01/01/2006

Document Version:

Publisher's PDF, also known as Version of record

\section{Please check the document version of this publication:}

- A submitted manuscript is the version of the article upon submission and before peer-review. There can be important differences between the submitted version and the official published version of record.

People interested in the research are advised to contact the author for the final version of the publication, or visit the DOI to the publisher's website.

- The final author version and the galley proof are versions of the publication after peer review.

- The final published version features the final layout of the paper including the volume, issue and page numbers.

Link to publication

\footnotetext{
General rights rights.

- You may freely distribute the URL identifying the publication in the public portal. please follow below link for the End User Agreement:

www.umlib.nl/taverne-license

Take down policy

If you believe that this document breaches copyright please contact us at:

repository@maastrichtuniversity.nl

providing details and we will investigate your claim.
}

Copyright and moral rights for the publications made accessible in the public portal are retained by the authors and/or other copyright owners and it is a condition of accessing publications that users recognise and abide by the legal requirements associated with these

- Users may download and print one copy of any publication from the public portal for the purpose of private study or research.

- You may not further distribute the material or use it for any profit-making activity or commercial gain

If the publication is distributed under the terms of Article $25 \mathrm{fa}$ of the Dutch Copyright Act, indicated by the "Taverne" license above, 


\title{
UNITED NATIONS
}

UNIVERSITY

\author{
UNU-MERIT
}

\section{Working Paper Series}

\#2006-015

\section{The Determinants of Pharmaceutical R\&D Expenditures: Evidence from Japan}

Jörg C. Mahlich and Thomas Roediger-Schluga

February 2006 



\title{
The Determinants of Pharmaceutical R\&D Expenditures: Evidence from Japan
}

\author{
Jörg C. Mahlich ${ }^{1}$ and Thomas Roediger-Schluga ${ }^{2}$
}

\begin{abstract}
During the past 20 years, the world pharmaceutical industry has experienced a dramatic increase in R\&D intensity. We apply and extend a model developed by Grabowski and Vernon (2000) with a pooled data sample of the 15 publicly listed Japanese drug firms for the period 1987 to 1998. As in the reference paper, we find expected returns to be an important determinant of R\&D spending in the Japanese drug industry, albeit considerably smaller than in the U.S., which is particularly obvious in the case of returns from newly introduced drugs. However, our results are sensitive to econometric model specification, in particular to controlling for serial correlation and to a dynamic specification of the baseline model. Likewise, estimates on financial constraints are sensitive to model specification, indicating that Japanese drug firms face small or no financial constraints. Our results are consistent with the general literature on $R \& D$ investment behaviour, yet raise some methodological questions with regard to the original study.
\end{abstract}

Keywords: R\&D, investment, panel data estimation, pharmaceuticals, Japan

JEL-classification: L65, O31, O33

\section{UNU-MERIT Working Papers \\ ISSN 1871-9872}

\section{UNU-MERIT Working Papers intend to disseminate preliminary results of the research carried out at the institute to attract comments}

\footnotetext{
${ }^{1}$ Economic Policy Department, Austrian Federal Economic Chamber, Wiedner Hauptstrasse 63, A-1045 Vienna, Austria, email joerg.mahlich@wko.at

2 Department of Technology Policy, ARC systems research, Donau-City-Strasse 1, A-1220 Vienna, phone +43 (0)50 550 4569, fax +43 (0)50 550 4599, email thomas.roediger@arcs.ac.at
} 



\section{INTRODUCTION}

During the past 20 years, the world pharmaceutical industry has experienced a dramatic increase in R\&D intensity. In a recent paper, Grabowski and Vernon (2000) explore the determinants underlying this trend in R\&D investment behaviour for a pooled sample of 11 major U.S. drug firms over the period 1974 to 1994. Estimating a static panel data model, they find that expected returns and cash flow are important explanatory variables of firm research intensities during this period.

In this paper, we explore whether similar conclusions also hold for the Japanese pharmaceutical industry. Given institutional differences and the differences in the way how firms are funded in the U.S. and Japan, there is good reason to expect divergent results. In particular, the U.S. is the only drug market in the world where prices are unregulated, and financial systems are quite different in the two countries.

Using a pooled data sample of the 15 publicly listed (and largest) Japanese drug firms for the period 1987 to 1998, we start out with the baseline model estimated by Grabowski and Vernon (2000). We then extend their model to accommodate for special features of the Japanese drug market and for econometric issues not dealt with in the reference paper. This aligns our results with the existing general literature on the determinants of investment in R\&D.

We find expected returns to be an important determinant of R\&D spending in the Japanese pharmaceutical industry. In absolute terms, however, R\&D spending is considerably less responsive than in U.S., in particular in a dynamic panel data model, which is a theoretically more appropriate specification. Likewise, sensitivity to cash flow is considerably smaller in Japan and disappears in the dynamic model formulation, confirming the result of other studies that Japanese firms face fewer or even no financial constraints.

The paper is structured as follows. In Section 0, we briefly highlight the particular features of $R \& D$, which impact the R\&D investment decision. In Section III, we describe recent trends in pharmaceutical R\&D in Japan and discuss the particularities of the Japanese drug market. In Section 0, we present the data and discuss our econometric model specifications. In Section 0, we list and interpret our estimation results. Section 0 summarises the paper and concludes with directions for future research. 


\section{THE R\&D INVESTMENT DECISION}

According to basic economic theory, a firm's R\&D investment decision is determined by the intersection of the marginal rate of return on investment schedule and the marginal cost of capital schedule. These are obtained by arranging potential investment projects in order of decreasing rates of return and the opportunity costs of alternative investment in increasing order. However, investment in R\&D differs from ordinary investment in a number of fundamental ways, which impact the way investment in R\&D is modelled.

First, and perhaps most importantly, a significant share of R\&D spending are wages and salaries of scientists and engineers, who create ideally profitable new knowledge. This knowledge is specialized, sunk and intangible, and its value hence very difficult to determine.

Second, even to the extent that R\&D produces tangible output, its ultimate value is uncertain and difficult to appraise ex-ante. Time horizons may be quite long, as in the pharmaceutical industry, where it takes 14 years on average at present to develop and introduce a new chemical entity (NCE) (see PhRMA 2003). Not only is the variance of the distribution of expected returns much larger than for other types of investment. Rather, returns to R\&D are highly skewed (Scherer et al. 2000) and appear to be fat-tailed, which may affect the computation of moments. In a recent paper, Silverberg and Verspagen (2005) estimate Pareto exponents $<1$ for various empirical data sets, showing that not even the first central moment (the mean) converges in these cases. In such situations, meaningful expected-rates-of-return cannot be calculated and standard risk-adjustment methods do not work any more.

Third, the cost of capital may differ considerably by source of funding. Empirical evidence typically shows a positive association between R\&D spending and cash flow, indicating a gap between the external and the internal costs of capital (for surveys, see Hubbard 1998; Hall 2002). Economic theory provides three main types of explanations: (i) asymmetric information between inventor and investor, (ii) moral hazard on the part of the inventor and (iii) distortions introduced by the tax system.

Information asymmetries arise because firms undertaking R\&D tend to be better informed about the quality and prospects of their R\&D projects than outside investors. These may therefore require a 'lemons' premium' (after Akerlof's (1970) seminal model of adverse selection) to cover the extra risk they incur, which raises the cost of external capital. Moral hazard stems from the principal-agent relationship between a firm's owner(s) and its managers. Because of imperfect monitoring, managers may either overinvest free cash flow in 
activities that benefit them (enhance their income, status, job security, etc.) or underinvest free cash flow in uncertain R\&D projects. In both cases, share-value is not maximised and there is an agency-cost induced gap between the cost of capital and the return to R\&D. Distortions introduced by the tax system are due to different levels of taxes levied on retained earnings, debt and equity. Typically, interest on debt can be expensed, while retained earnings are subject to capital gains tax, and new share issues are subject to personal tax and capital gains tax on dividends. However, debt is usually serviced from cash flow, which reduces the amount available to sustain a productive $R \& D$ programme. This opportunity cost may more than offsets any tax advantage of debt, rendering retained earnings the cheapest source of funding R\&D. The surveys by Hall (2002) and Hubbard (1998) list ample empirical evidence in support of each of these theoretical arguments.

Empirical studies show that financing constraints are mediated by the institutional set-up of countries' financial system. Bond et al. (2003) compare the impact of cash flow on physical and R\&D investment in Britain and Germany in the high-tech sector over the period 19851994. They find significant constraints in the UK but not in Germany, which they attribute to differences induced by the stock-exchange based system in the UK and the bank-based system in Germany. Mulkay et al. (2001) compare the U.S. with France and find that internal funds are more important for physical and R\&D investment in the USA than in France. Hall et al. (1999) analyze large samples of firms in R\&D intensive industries in the USA, Japan and France. They find that investment in fixed capital and R\&D are sensitive to cash flow only in the USA. Their results support the notion that firms in France and Japan face weaker financing constraints.

The theoretical considerations have two consequences for modelling the R\&D investment decision. First, depending on the institutional framework they are operating in, firms are not indifferent to their source of funding. Rather, capital market imperfections yield the marginal cost of capital (mcc) curve depicted schematically in Figure 1. It consists of two horizontal segments, one representing the lower cost of internal funds (free cash flow) and the other the higher cost of new equity financing. The rising connecting segment stands for the cost of new debt financing. $R^{*}$, the optimal amount of $R \& D$ investment is given by the intersection of the marginal rate of return (mrr) and the mcc curve. Obviously, an increase in free cash flow shifts the mcc schedule to the right (mcc') which raises $\mathrm{R}^{*}$ to $\mathrm{R}^{*}$. Similarly, higher expected 
returns to R\&D shift the mrr schedule upwards (mrr'), also raising the optimal amount of $\mathrm{R} \& \mathrm{D}$ investment to $\mathrm{R}^{* 13}$.

Figure 1: The R\&D investment decision

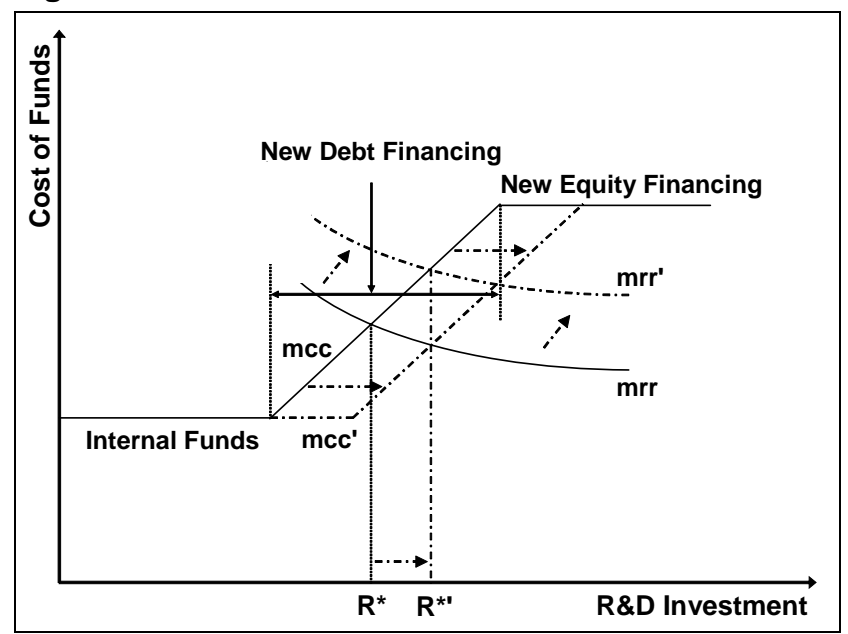

Source: adapted from Grabowski and Vernon (2000, pp. 207-208)

Second, in light of the characteristics of R\&D investment described above, there are reasons to expect an autonomous component in R\&D investment behaviour. The more difficult it is to compute an exact measure of the expected returns to $R \& D$, the more likely it is that firms will apply simple decision rules to determine their R\&D investment (e.g. a certain share of revenues). An additional element of sluggishness is introduced by the fact that R\&D enhances firms' knowledge bases, which is mainly embodied in their employees, especially their R\&D personnel. If these leave or are dismissed, firms may lose valuable resources. So as to hold on to them, firms tend to smooth their R\&D investment over time (see Hall 2002).

The foregoing discussion has highlighted the pivotal role of institutional factors for firms' R\&D investment behaviour. Before specifying our model, we therefore need some background information on R\&D in the Japanese pharmaceutical industry. This will be given in the next section.

3 For expositional clarity, we show only shifts of either the mcc or the mrr curve of equal size, yielding the same new optimum $\mathrm{R}^{*}$. 


\section{R\&D IN THE JAPANESE PHARMACEUTICAL INDUSTRY}

$R \& D$ in the pharmaceutical industry is driven by the search for the next 'blockbuster' drug. These 'blockbusters' are a very small number of highly innovative drugs that account for a disproportionate share of profits realised by individual firms and the entire industry (Grabowski and Vernon 1994). For example, the three leading products in 2002 - Lipitor and Zocor, two cholesterol lowering drugs, and Losec/Prilosec, an anti-ulcer drug - had global sales of USD 20.0 billion (IMS HEALTH 2003). Since the late 1970s, the rate of such major drug innovations has increased significantly (see Grabowski and Vernon 2000). This is due to greater technological opportunity, brought about by major process innovations ${ }^{4}$ in the way how R\&D is conducted and more targeted search thanks to advances in scientific understanding.

This trend has coincided with a dramatic increase in R\&D spending by pharmaceutical firms. As shown by PhRMA (1999), aggregate R\&D intensity (R\&D-to-sales ratios) has almost doubled from 10.9 to $20.0 \%$ between 1974 and 1998. A similar trend is also observable in Japan (see Figure 2), where the aggregate R\&D-to-sales ratio of the 15 largest publicly listed pharmaceutical firms has risen from 9\% in 1987 to 13.5\% in 1998 in an almost linear fashion. Which factors stand behind this development? For the U.S., Grabowski and Vernon (2000) identify two variables, expected returns to R\&D and cash flow. They argue that thanks to the higher number of major new drug innovations expected returns to $R \& D$ investment have increased in recent years, while the expanding industry cash flow generated by these innovations has provided a readily available (and relatively low cost) source of funds to finance R\&D (Grabowski and Vernon 2000, pp. 205-206). Can a similar argument also be made for Japan?

Which factors stand behind this development? For the U.S., Grabowski and Vernon (2000) identify two variables, expected returns to R\&D and cash flow. They argue that thanks to the higher number of major new drug innovations expected returns to $R \& D$ investment have increased in recent years, while the expanding industry cash flow generated by these innovations has provided a readily available (and relatively low cost) source of funds to

$4 \quad$ These include combinatorial chemistry, through which structurally related molecule variations are mass-produced through the parallel synthesis of combinations from any number of starting substances, high throughput screening, the parallel testing of a very large number of compounds in parallel at a micro scale by automated robots, and the use of ever more powerful computers and computer software, which allow to analyse the wealth of available information in more comprehensive ways, and - along with breakthroughs in visualisation technology - help to accelerate the growth of scientific understanding. 
finance R\&D (Grabowski and Vernon 2000, pp. 205-206). Can a similar argument also be made for Japan?

Figure 2: Aggregate R\&D-to-sales of 15 publicly listed Japanese drug firms

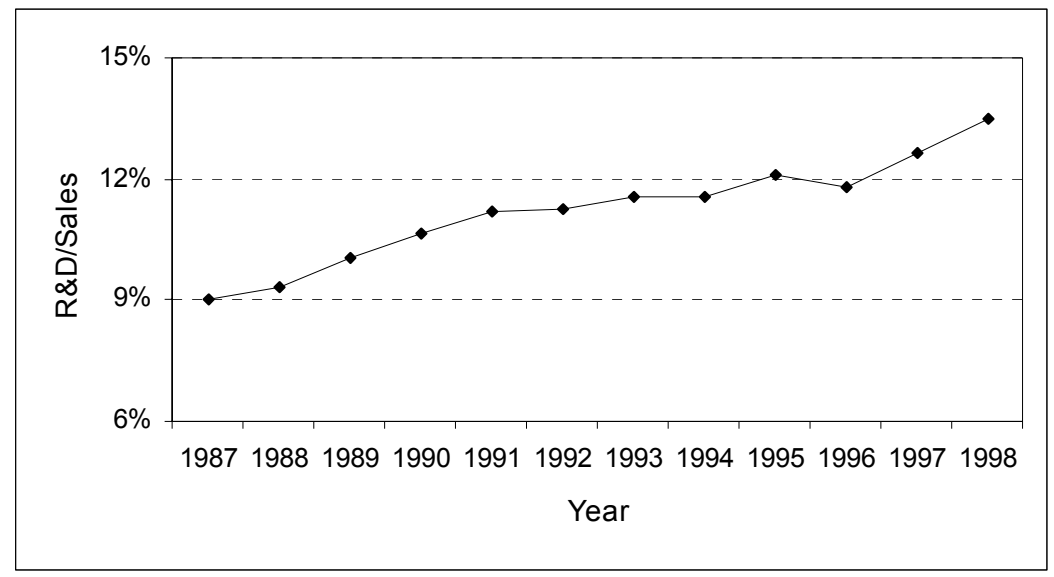

Source: Morgan Stanley Dean Witter (1998)

As opposed to their international rivals, Japanese pharmaceutical companies generate most of their revenues domestically. For example, in 1997, the export ratio of the top ten Japanese drug firms ranged from 2.3\% (Shionogi) to 18.6\% (Sankyo). In comparison, in the same year, Bristol Myers Squibb generated 31.9\% of its revenues abroad and Novartis even 98.1\% (Morgan Stanley Dean Witter 1998). Therefore, the economic decisions of Japanese drug firms are almost exclusively determined by the situation in their home market.

In principle, drug market fundamentals are very favourable in Japan. Along with France, Japan has the highest per capita drug consumption among OECD countries. In 1997, drugs accounted for $21 \%$ of total health spending in Japan, compared to merely $8.4 \%$ in the U.S. (OECD 1997). The share of senior citizens (aged above 65), who account for more than half of total drug consumption, is predicted to rise from $17 \%$ in 2000 to $26 \%$ in 2025 , the highest share among OECD countries (Koseisho 1996). This matters even more as health-related expenditures tend to rise with age and senior Japanese citizens spend almost five times more than those aged below 65 (Oliver et al. 1997). As a result, the Japanese Ministry of Health estimates that health spending will rise by around 150\% in real terms between 1997 and 2025. The reason why Japanese take so many pills lies in the way how prices are determined and how drugs are distributed. Drug prices are set by the Central Social Insurance Medical Council (chuikyo). Distribution mainly takes place via doctors rather than pharmacies. This gives the former an incentive to liberally prescribe drugs, especially those with high profit margins. These margins, called yakka-saeki, arise from the difference between wholesale prices and official list prices, set by chuikyo, at which doctors are reimbursed by the health 
insurance companies. For the year 1987 only, the margin was estimated to be in the order of USD 9 billion (Reich 1990) to USD 13 billion (Hisashige 1997).

In order to reign in the exploding health bill, the Ministry of Health regularly checks pharmaceutical firms' and wholesalers' books to determine the difference between market and list prices and adjusts the latter to the former. This leads to biannual price cuts (on average) of sometimes more than $10 \%$. These price cuts do ease pressure on the public health bill, but have significant impacts on the drug market. Because of the downward price spiral, the average life span of a drug is considerably shorter than elsewhere. While the average drug is sold for 10.8 years in the U.S. and 12.9 years in the UK, this period is only 7.9 years in Japan (Huttin 1995). Shorter drug lifecycles reduce the incentive to undertake extremely risky and expensive investments in breakthrough medicines, which require long pay-back periods to cover their development costs. An 'innovation premium', introduced in 1992 and increased in 1996, which grants price surcharges to new innovative medicines of up to $60 \%$ compared to existing substitutes, has not altered the situation. As a result, only $13 \%$ of 'significant new drugs' that were registered and distributed in at least six countries were made available in Japan between 1995 and 1998 (Thomas 2001).

Because of the lower market potential of innovative medicines, technological novelty is less important than skilful marketing for commercial success. This is illustrated by the fact that $45 \%$ of the employees of Japanese pharmaceutical firms work in marketing or sales departments, compared to 30\% in the U.S. (McLellan 1997). As a consequence, we expect new drug sales to be a relatively smaller stimulus for R\&D investment in Japan than Grabowski and Vernon find in the U.S.

Hypothesis 1: Because of the regulatory environment, $R \& D$ investment in Japan is insufficiently rewarded. The success of a new medicine is less a function of its innovative content than of a host of other factors, above all marketing expenditures. Therefore, we expect a smaller elasticity of $R \& D$ investment with regard to sales of new drugs than in the United States.

The second explanatory variable considered by Grabowski and Vernon (2000) is the availability of cash flow. As argued above, most R\&D is funded internally as markets for financing R\&D tend to be incomplete. In this context, venture capital may be a cheap external source of funding, which has become particularly important in funding small, mostly sciencebased new and young firms (such as in the biotech industry). However, the firms we study in this paper are large and established pharmaceutical companies. Moreover, during the period 
considered in this paper, the venture capital industry was far less developed in Japan than in the U.S. or (even) Europe (see OECD 2001).

Grabowski and Vernon (2000) show that the availability of cash-flow has increased in recent years in the U.S. pharmaceutical industry, providing ample funding opportunities. Although this is also true of Japan (see Figure 3), there are reasons to expect that Japanese firms are less reliant on cash flow in their investment decisions than their U.S. rivals.

Figure 3: Aggregate cash-flow/sales, 1987-1998

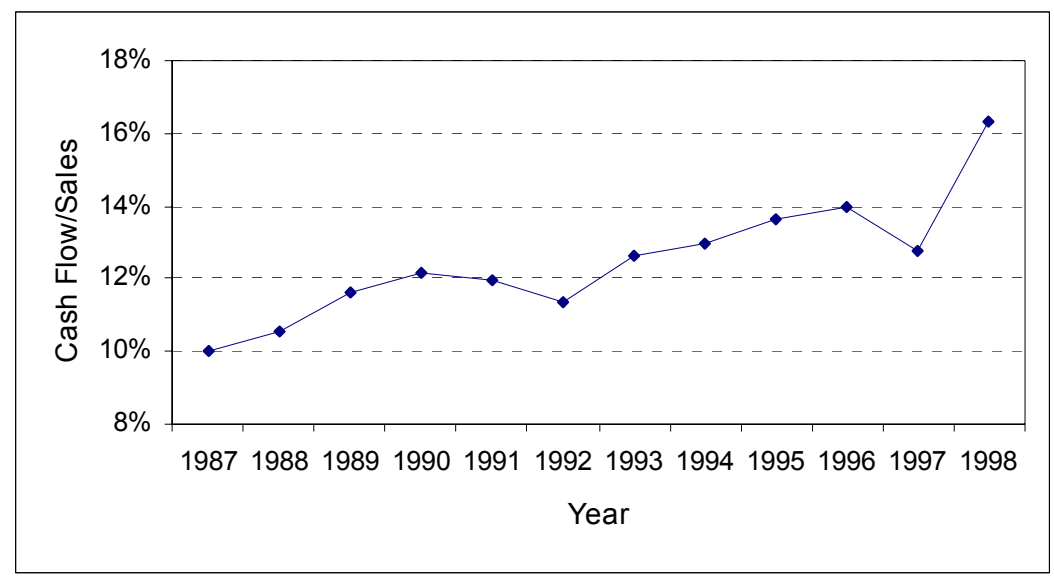

Source: Morgan Stanley Dean Witter (1998)

Japan's financial system is bank-based, rather than stock-exchange based as in the U.S. In a bank-based financial system, the main source of external funding is banks, both for private firms and the small number of publicly listed large firms. Bank lending is relational, i.e. each loan is seen as part of a long-term relationship in which a firm grants the bank full access to its books in return for influence over its policy and personnel and committed support through bad times. Much lending is long-term and where firms borrow from more than one bank, one of them is usually recognised as 'lead' or 'house' bank and maintains oversight of the firms' financial positions (Tylecote 1994, p. 261). This is particularly true of keiretsus, large industrial groupings organised around a bank. These are mainly based on financial aspects (provision of loans, mutual shareholding, etc.) and opportunities to exchange information, rather than the transaction of goods (Miarka 1999, p. 4).

To the extent that the close ties between firms and banks allows better monitoring and reduces information asymmetries, the cost of external funds are lower (confirmed empirically by Miarka 1999) and cash flow has a smaller effect on investment, holding constant investment opportunities (see Hubbard 1998; Hall et al. 1999). For Japan, it has indeed be shown that liquidity effects on investment are (at least historically) less important for firms belonging to a keiretsu than for firms that are not part of such a group (see Hoshi et al. 1991). Also, those 
firms with access to a bank should have lower costs of capital because of lower information costs, which should increase returns in the long run. Historically, this indeed used to be true of returns on R\&D investments in Japan (e.g. Griliches and Mairesse 1990). For a recent survey on firm-bank relationships in Japan see Hoshi and Kashyap (2001).

Hypothesis 2: Thanks to their close ties with banks, Japanese firms have ready access to relatively cheap and long-term external funds. As a consequence, the $R \& D$ investment decision of Japanese firms is less dependent on internally generated cash flow. Therefore, we expect a smaller elasticity of $R \& D$ investment with regard to the availability of free cash flow than in the United States. 


\section{DATA AND ECONOMETRIC MODEL SPECIFICATIONS}

In the following, we will test the two hypotheses with data on Japan for the period 1987-1998.

Our sample consists of all 15 publicly listed Japanese pharmaceutical firms, i.e. Banyu, Chugai, Daiichi, Eisei, Fujisawa, Kissei, Ono, Sankyo, Santen, Shionogi, Seikagaku, Taisho, Takeda, Tanabe and Yamanouchi. Firm and market data have been obtained from Morgan Stanley Dean Witter Tokyo.

For comparative purposes, we start out with the baseline model estimated by Grabowski and Vernon (2000), $R D S_{i t}=f\left(E \pi_{t}, C F S_{i t-1}\right)$, where $R D S_{i t}$ is R\&D normalised by sales for firm $i$ in year $t, E \pi_{t}$ is an index of expected returns to R\&D in pharmaceuticals in year $t$, and $C F S_{t-1}$ is cash flow divided by sales for firm $i$ in year $t-1$.

The typical proxy for investment opportunities in the literature is Tobin's $q$ or some variation of it (see Gugler et al. 2003). However, this is an unspecific measure for all types of investment. In this paper, we prefer to use measures that capture expected returns to $R \& D$ more specifically. We use two measures for the $E \pi_{t}$ variable. The first measure, NEWSALES, is a kind of industry level R\&D productivity index, which is defined as the sum of estimated peak revenues from new drug introductions in year $t$, divided by aggregate real R\&D expenditures in year $t .^{5}$ Peak revenue estimates are from Morgan Stanley Dean Witter. According to analysts, this measure sufficiently describes the entire revenue life cycle of a drug. It is assumed that a high R\&D productivity at the industry level lets managers become more optimistic about their firms' prospects and induces them to raise R\&D spending. Moreover, firms may benefit from knowledge generated by other firms' R\&D efforts (see Henderson and Cockburn 1996).

NEWSALES captures the productivity of current R\&D in terms of sales generated by new drug introductions. The second measure, INDMARG (short for industry margin), is the weighted average profit rate of the entire industry, expressed as pre-tax profits divided by sales. It captures the price-cost margin of sales of both new and established products. While being a function of R\&D performance, it also reflects other economic forces affecting the industry, in particular the impact of regulatory interventions. Since the value of R\&D output

$5 \quad$ Note that Grabowski and Vernon (2000) construct NEWSALES as a measure of recent R\&D productivity by using lagged values. Although preferable from a theoretical point of view, data constraints prevented a similar construction in this paper. 
is highly uncertain and difficult to determine, and managers therefore do not know about the future profitability of their firms, we assume that expectations are formed on the basis of the most recent available data. We assume that if industry margins rise, managers become more optimistic about their firms' fate and raise R\&D spending.

Figure 4 plots the NEWSALES and INDMARG variable. It shows that measured by the NEWSALES variable, industry R\&D productivity has declined during the observation period. This is in stark contrast with the U.S., where Grabowski and Vernon (2000) find a rising trend from the mid-1970ies to the mid-1980ies and a stable performance at a high level until the mid-1990ies. Furthermore, Figure 4 shows that although somewhat less profitable in absolute terms, Japanese pharmaceutical firms have recorded a comparable increase in industry profit margin as their U.S. peers during the observation period.

Figure 4: NEWSALES and INDMARG index, 1987-1998

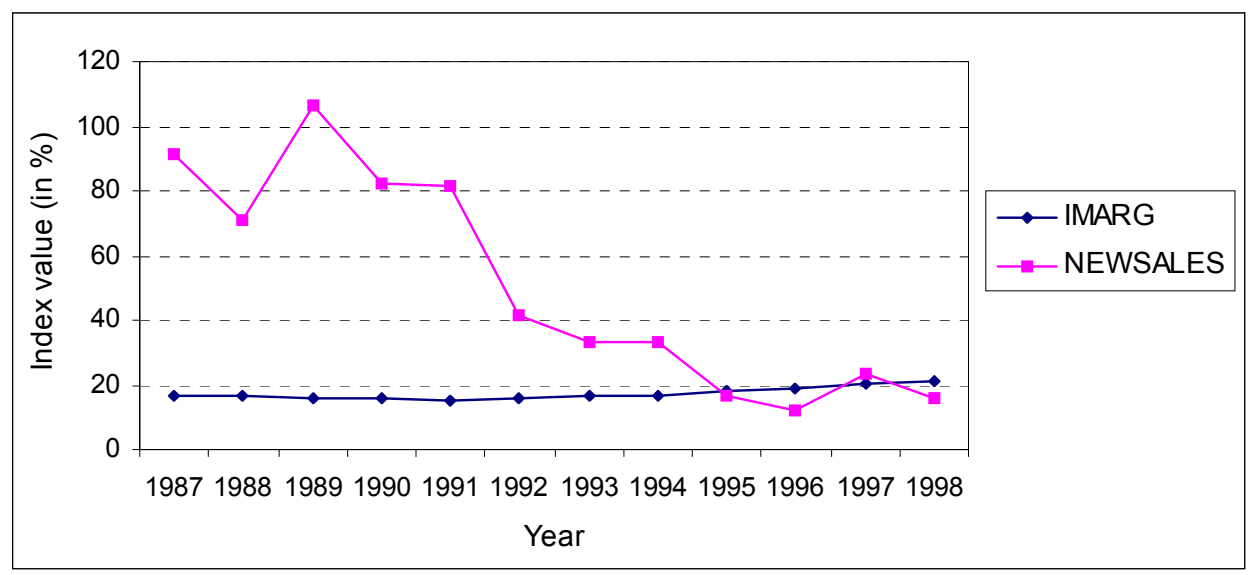

Source: Morgan Stanley Dean Witter (1998), own calculations

Breaking down the variable by its components (see Figure 5) shows a constant to falling number of innovative NCEs being introduced each year. Similarly, sales per new products rather decline over time. 
Figure 5: Number of new drug introductions and generated peak sales

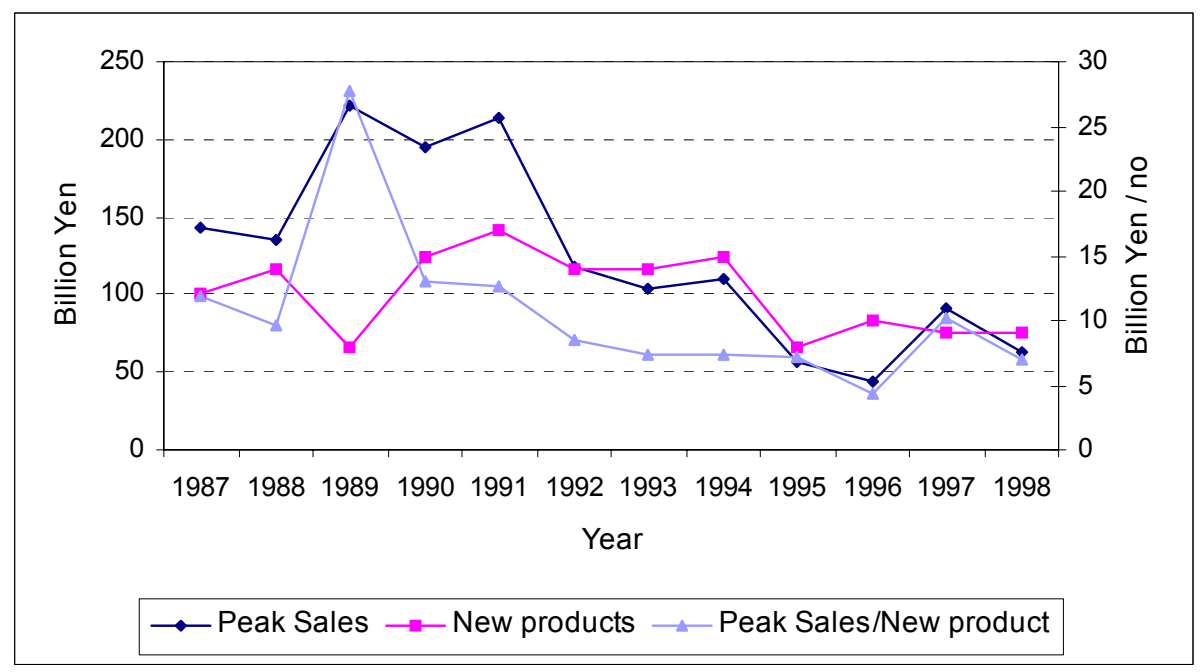

Source: Morgan Stanley Dean Witter (1998)

The third variable in this regression model, $\mathrm{CFS}_{\mathrm{t}-1}$, is the cash flow-to-sales ratio in period $t-1$. Cash flow is computed as the sum of net profits before dividend payments, depreciation and after-tax R\&D expenditures. Since $R \& D$ is expensed for tax purposes, one must add back 'after-tax R\&D outlays' to arrive at correct pre-investment cash-flows (Hall 1992). After-tax $\mathrm{R} \& \mathrm{D}$ expenditures are computed as $\left(1-T_{E}\right) \times I$, where $T_{E}$ is the effective tax rate and $I$ is R\&D spending. ${ }^{6}$ Figure 3 above, which plots the evolution of the aggregate CFS variable for all firms, shows an increase for most of the years during the observation period, with brief slumps in 1991, 1992 and 1997.

To account for unobserved heterogeneity in our sample we estimate a fixed-effects specification of our baseline model,

$$
R D S_{i t}=\beta_{1} I N D M A R G_{i t}+\beta_{2} C F S_{i t-1}+\beta_{3} N E W S A L E S_{i t}+\alpha_{i}+\varepsilon_{i t}
$$

\footnotetext{
6 Company taxes in Japan consist of 'corporate taxes' and 'local taxes', which are collected by the cities and prefectures. 'Corporate taxes' for companies with an equity capital of more than Yen 100 million have been 30\% of profits since April 1, 2000 (formerly 34.5\%). Smaller firms with an equity capital of less than Yen 100 million pay 20\% taxes (formerly $25 \%$ ) on profits of up to Yen 8 million. Apart from the corporate tax, there is an 'enterprise tax' of $12 \%$ and a 'resident tax', which consists of two parts: 1 . A 'prefecture tax', which amounts to $5 \%$ of the 'corporate tax', i.e. $30 \%$ x $5 \%=1.5 \%$. 2. A 'city tax', which is $12.3 \%$ of the 'corporate tax', i.e. $12.3 \% \times 30 \%=3.69 \%$. The total nominal tax rate thus amounts to 47.69\%. However, since the 'enterprise tax' can be deducted from the tax base, the effective tax rate is only $42.13 \%$. An example: For a profit of Yen 100, the tax base is 89.29 [100/(1+0.12)]. 'Corporate taxes' amount to Yen 26.79 (89.19 x 30\%) and 'enterprise taxes' are Yen 10.71 (89.29 x 12\%). The 'prefecture taxes' are Yen 1.34 (26.79 x 5\%) and the 'city tax' is Yen $3.29(26.79 \times 12.3 \%)$. The information on the Japanese tax system has been obtained from Tadahisa Koga from NISTEP, Tokyo.
} 
where $\alpha_{i}$ is the firm-specific, time-invariant constant term. A Hausmann specification test shows no difference between a fixed- and a random effects specification. Therefore, we focus on the fixed-effects model, which can be estimated by straightforward OLS.

As a first extension of Model 1, we add two control variables. To control for the impact of normalising R\&D by sales, we introduce firm sales as right-hand side variable SALES. There is an extensive literature on the relationship between R\&D spending and firm size, known as the 'Schumpeter hypothesis' (for a survey, see Cohen 1995). Most studies find a U-shaped relationship with small and very large firms being relatively more $R \& D$ intensive (subject to inter-industry variations, see e.g. Acs and Audretsch (1991)). Japanese pharmaceutical firms are large by conventional measures, yet small by international standards. What this implies for R\&D intensity is an open question a-priori.

To capture the impact of the biannual price cuts described in Section 0, we construct a second control variable, dubbed SURPRISE, which measures the difference between actual and expected price reductions. Although firms know that prices are cut in odd years, they do not know by how much. We assume that firms form their expectations by averaging all price cuts from time $t_{\text {start }}$, our first observation, to $\mathrm{t}-1$. In even years, when no price cuts are expected, SURPRISE takes on the value 0 . Since price cuts are announced at the beginning of each $t_{\text {odd }}$, and the other variables we use are reported at the end of each year, we do not lag the variable in our estimations. We expect that larger-than-expected price reductions have a negative impact on R\&D intensities as managers become less optimistic about future market conditions.

Adding the two control variables, we thus estimate $R D S_{i t}=\beta_{1} I N D M A R G_{i t}+\beta_{2}$ CFS $_{i t-1}+\beta_{3} N E W S A L E S_{i t}+\beta_{4} \operatorname{SALES}_{i t}+\beta_{5}$ SURPRISE $_{t}+\alpha_{i}+\varepsilon_{i t}$ as our second model.

Next, we further extend Model 2 to correct for possible serial correlation in the error terms. Most time-series data is correlated over time, and in such a situation the OLS estimator no longer yields an unbiased estimate of the variance-covariance (VC) matrix. Although parameter estimates remain asymptotically unbiased, the biased VC matrix affects interval estimates and makes hypothesis testing unreliable. The classical solution to this problem in the standard regression model is to include an AR(1) term to remove any first-order autocorrelation in the disturbances $\varepsilon_{i t}$. Baltagi and Wu (1999) develop a feasible generalised least squares (FGLS) procedure that applies this solution to the panel data case. For equally 
spaced data with no missing observations, their model is equivalent to a Prais-Winsten transformation in the $\operatorname{AR}(1)$ model. The error term $\varepsilon_{i t}$ is modelled as $\rho \varepsilon_{i t-1}+z_{i t}$, with $\rho<1$ and $z_{i t}$ distributed identically and independently. There are several ways to specify $\rho$. In our case, $\rho$ is defined as 1-DW/2, where DW is the Durbin-Watson $d$ statistic. Apart from solving the econometric problem caused by first-order autocorrelation, the method has the additional advantage of keeping the model comparable to our baseline model. Model 2 thus becomes $R D S_{i t}=\beta_{1} I N D M A R G_{i t}+\beta_{2}$ CFS $_{i t-1}+\beta_{3} N$ WSALES $_{i t}+\beta_{4}$ SALES $_{i t}+\beta_{5}$ SURPRISE $_{t}+\alpha_{i}+\rho \varepsilon_{i t-1}+z_{i t}$

Models 1-3 are static specifications. However, theoretical considerations suggest that dynamic model in which lagged R\&D spending appears on the right-hand side may in fact be a more appropriate specification. As highlighted in Section 0, R\&D investment behaviour may have a strong autonomous component and be much less responsive to external variables than a static model would suggest. We therefore also consider a dynamic model of the form $R D S_{i t}=\beta_{1} I N D M A R G_{i t}+\beta_{2}$ CFS $_{i t-1}+\beta_{3}$ NEWSALES $_{i t}+\beta_{4}$ SALES $_{i t}+\beta_{5}$ SURPRISE $_{t}+\beta_{6}$ RDS $_{t-1}+\alpha_{i}+\varepsilon_{i}$

where $\mathrm{RDS}_{\mathrm{t}-1}$ is $\mathrm{R} \& \mathrm{D}$ spending normalised by sales lagged by one period.

In estimating this model, we have to depart from the LS-framework because of the potential endogeneity of the lagged dependent variable and the presence of other potentially endogenous right hand side variables. Instead, we will use the systems GMM estimator developed by Blundell and Bond (1998) and applied in a similar context by Bond et al. (2003). For panels that are short in time and include persistent time series (such as our data set), Bond (2002) has shown that this estimator produces more efficient results in finite samples than standard GMM estimators which eliminate unobserved firm-specific effects by taking first differences (see Arellano and Bond 1991). The Blundell-Bond estimator combines in a system the regression in differences with the regression in levels. The instruments for the regression in differences are the lagged levels of variables consistent with the moment conditions. For the other component of the system, the equation in levels, the instruments are given by the lagged differences of the variables (see Bond 2002 for an accessible exposition of the estimation technique).

We utilise the two-step variant of the Blundell-Bond system GMM estimator. This is asymptotically more efficient than the one-step variant, yet produces estimates of the standard errors that are biased downwards. Therefore, we apply the finite-sample correction to the twostep VC matrix developed by Windmeijer (2005) that leads to more accurate finite sample inference. 


\section{ESTIMATION RESULTS AND INTERPRETATION}

The estimation results are displayed in Table 1. For comparative purposes, we show the results of the baseline model estimated by Grabowski and Vernon (2000) in the first column. For all model specifications, an F-test rejects the hypothesis that all parameters are equal to zero. In Model 3, a $\rho$ value of 0.575 validates our conjecture of significant first-order serial correlation. In Model 4, the coefficient of the lagged dependent variable is close to unity, which supports our choice of the system GMM estimator. For the two-step systems GMM estimation, the Hansen J statistic, which is robust to non-spherical disturbances, indicates that the orthogonality conditions underlying the GMM estimator are valid. Goodness-of-fit measures $\left(\mathrm{R}^{2}\right)$ are remarkably high for panel data estimation. Estimation results are quite robust across the different specifications, which makes us fairly confident as to the validity and reliability of our findings.

Turning to our first hypothesis, parameter estimates for INDMARG are statistically significant in each of the specifications and produce quite sizeable absolute effects. For the static specifications (Models 1-3), they range from 0.322 to 0.532 . Controlling for firm size and the impact of the pricing regime does not have a substantial impact on parameter estimates. However, including an AR(1) term in Model 3 nearly doubles the parameter estimate of the baseline model. In the dynamic specification (Model 4), the coefficient for INDMARG declines to 0.18 , which was to be expected from controlling for autonomous R\&D investment behaviour. Since INDMARG is the fraction of industry pre-tax profits divided by industry sales, our estimates suggest that a $1 \%$ increase (decrease) in industry profit margin will lead to an approximate 0.17 to $0.53 \%$ increase (decrease) in R\&D expenditures, which is about one quarter to two thirds the impact estimated by Grabowski and Vernon for the U.S.

Table 1: Regression output

\begin{tabular}{lccccc}
\hline & G\&V (2000) & Model 1 & Model 2 & Model 3 & Model 4 \\
\hline Constant & $-0.18(10.32)^{* * *}$ & $6.296(4.09)^{* * *}$ & $6.898(3.68)^{* * *}$ & $3.408(3.72)^{* * *}$ & $-1.58187(0.95)$ \\
INDMARG & $0.77(9.47) * * *$ & $0.322(4.09)^{* * *}$ & $0.329(4.14)^{* * *}$ & $0.532(6.01)^{* * *}$ & $0.178(1.96)^{* *}$ \\
Cash Flow & $0.12(4.14)^{* * *}$ & $0.058(1.90)^{*}$ & $0.062(2.00)^{* *}$ & $0.041(1.65)$ & $0.027(0.44)$ \\
NEWSALES & $0.08(2.49)^{* * *}$ & $-0.020(-4.43)^{* * *}$ & $-0.022(4.08)^{* * *}$ & $-0.007(-1.26)$ & $0.003(0.52)$ \\
SALES & - & - & $-3.44 \mathrm{e}-06(0.64)$ & $-2.57 \mathrm{e}-05(-3.29)^{* * *}$ & $-4.38 \mathrm{e}-06(1.44)$ \\
SURPRISE & - & - & $0.014(0.59)$ & $0.083(1.39)$ & $0.007(0.25)$ \\
$\rho$ & - & & & 0.575 & \\
RDS ${ }_{\mathrm{t}-1}$ & & & & & $0.948(7.74)^{* * *}$ \\
$\mathrm{R}^{2}$ within & 0.92 & 0.444 & 0.457 & 0.279 & 164 \\
$\mathrm{~N}$ & 164 & 179 & 179 & 179 & 67.00 \\
$\mathrm{~F} / \mathrm{X}^{2}$ & 141.0 & 42.85 & 25.66 & 18.89 &
\end{tabular}




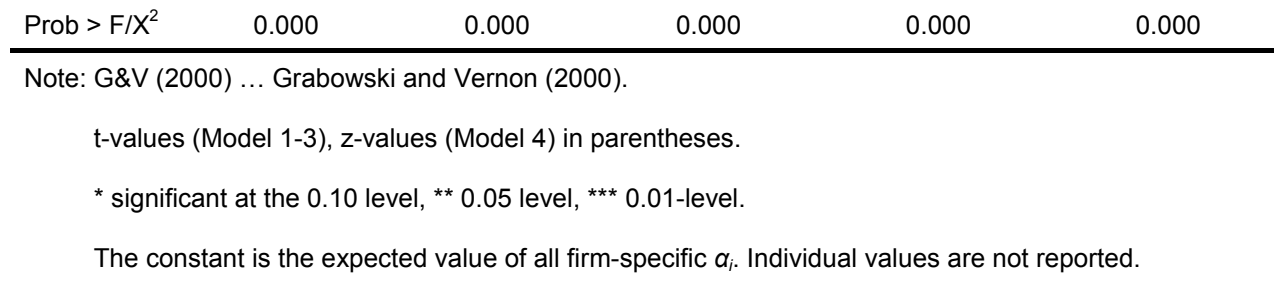

There are two substantive explanations for this discrepancy (differences due to alternative estimation approaches will be dealt with separately below). First, industry profit margins have been higher in the U.S. (24-29\% in the period 1980-1994) than in Japan (15-22\% during the observation period). Second, as pointed out in Section 0, Japanese drug firms spend about three times as much on marketing as on R\&D. Accordingly, marketing budgets may be the first to respond to changes in economic conditions while R\&D budgets may be relatively more autonomous. However, this point has to remain speculative as we do not have disaggregated data on firm spending.

Parameter estimates for the NEWSALE variable are less robust and small in absolute size. In Models 1 and 2, the coefficient of the NEWSALE variable is in the range of -0.02, about one quarter of the value estimated by Grabowski and Vernon. It is significant at the 0.01 level and has the correct sign, as our index of R\&D productivity has declined over time (see Figure 4). This fall is most probably the result of Japanese health policy, which attempts to attack exploding health costs by reducing the costs of new drugs. As a result, margins on new drugs are considerably lower than in the U.S. However, the coefficient value slumps in absolute value and loses statistical significance in Model 3, which controls for first-order serial correlation, as well as in the dynamic Model 4. The latter results suggest that sales generated by newly introduced drugs have no substantial impact on the R\&D investment behaviour of Japanese pharmaceutical firms.

Taken together, these results confirm our first hypothesis, which stated that institutional differences in the way innovation in the pharmaceutical industry is rewarded in Japan would mute the incentive effect of expected profits.

Coefficient estimates for the cash flow variable are also not robust to differences in model specification. For Models 1 and 2, which closely resemble the reference model, estimates are significant, albeit only at the 0.1 level in Model 1 . In absolute terms, parameter estimates range from 0.058 to 0.062 , i.e. a $1 \%$ increase (decrease) in the cash flow-to-sales ratio is estimated to increase (decrease) $R \& D$ expenditures by approximately $0.06 \%$. This is about half the size of the effect found for the U.S. In Models 3 and 4, the coefficients for the cash flow variable are no longer significantly different from zero. These results confirm our second 
hypothesis which stated that thanks to institutional differences in the financial system, Japanese pharmaceutical firms would face smaller financial constraints than their U.S. peers. In fact, Models 3 and 4 indicate that they are not subject to any external financial constraint. Although none of the firms included in our sample is part of a keiretsu, they nevertheless appear to have sufficiently close ties to banks and hence lower costs of external funding, which allows them to smooth out hikes in the availability of internal funding. This result is in line with the study by Hall et al. (1999).

Of the control variables, coefficient estimates for SALES are tiny in absolute value in all specifications and only statistically significant in Model 3. To the extent that there is any link between firm size and $R \& D$ intensity, the negative sign suggests that $R \& D$ intensity declines marginally with firm size. The coefficient of the SURPRISE variable, which attempts to capture the specificities of the way drug prices are set in Japan, is never significantly different from zero.

The coefficient of the lagged dependent variable in Model 4 shows that R\&D investment is indeed quite sluggish, as theoretical considerations suggest (see Section 0). Apart from the fact that firms may be unable to precisely tailor their R\&D budgets to changes in external conditions and that they may want to hold on to their intangible assets, which are embodied in their R\&D personnel, the result ties in with a broader question: Given the current unfavourable regulatory environment, why do Japanese firms continue to step up investment in $R \& D$ ?

Apart from having to maintain their absorptive capacity (see Cohen and Levinthal 1989, 1990), there is another and possible more important reason: An overwhelming share of profits in the pharmaceutical industry is generated by new drugs and Japanese pharmaceutical firms want to stay in business. As argued by Sharp and Patel (1997), a high current R\&D intensity may not necessarily be a sign of innovative success. Instead, it may be a response to past failure in an attempt to move to virtuous cycle in which intensive R\&D leads to a high number of successful products. So as not to fall further behind their international rivals, Japanese firms have to match their R\&D efforts.

Our results also raise methodological questions. Differences in model specification were shown to impact estimation results quite strongly. Of the three main explanatory variables considered, only industry profit margin remained significant after controlling for first-order serial correlation and autonomous R\&D investment behaviour. This is an important result, as it conforms to theoretical expectations. However, it casts doubt on the validity of the results 
obtained in the reference paper (Grabowski and Vernon 2000), which controls for neither effect. Replicating their study with more sophisticated estimation techniques might affect results in a similar manner as in this paper and yield qualitatively different results.

A final interesting point is the impact of turbulences in Japanese financial markets during our observation period. As is well-known, Japanese stock markets rallied until 1991. Since then, stock prices have fallen more or less consistently for the rest of the 1990ies. Splitting the data set into the period 1987-1991, when the bubble burst, and 1992-1998, and repeating the above estimations refine our findings. For the post-1991 period, parameter estimates remain more or less unchanged (significance decreases, which is to be expected from a lower $n$ ). For the period up to 1991, however, the INDMARG variable becomes significantly negative. In other words, even though profit margins were decreasing at that time, the general euphoria driving the bubble in the stock market appears to have induced managers in the pharmaceutical industry to further step up investment in R\&D. 


\section{SUMMARY AND IMPLICATIONS FOR FUTURE RESEARCH}

In this paper, we have tested and extended a static panel data model developed by Grabowski and Vernon (2000) to explain R\&D expenditures in the U.S. pharmaceutical industry for the 15 publicly listed Japanese pharmaceutical firms over the period 1987 to 1998. Akin to Grabowski and Vernon (2000), we find expected returns to be an important determinant of $R \& D$ investment. However, the effect is considerably smaller in Japan and sensitive to econometric model specification, above all in a theoretically more appealing dynamic panel data model. This is particularly obvious in the case of returns from newly introduced drugs, which cease to be significant in more sophisticated model specifications. Substantively, this is an alarming result, as it clearly highlights the dangerous incentive effect of recent regulatory attempts to curb an exploding public health bill. Unless Japanese firms are adequately rewarded for developing and marketing innovative drugs, they may lose out to their international rivals in an industry driven by innovative success.

Moreover, we find that Japanese pharmaceutical firms face smaller financial constraints than their US rivals. Depending on the model specification, constraints are either small or nonbinding. Similar results have been obtained in other studies and can be explained by the closer relationship between firms and sources of external finance in a bank-based financial system. Finally, the sensitivity of our results to different model specification highlights the risk of obtaining misleading estimation results. Firm-level data on R\&D investment is characterised by considerable serial correlation, while R\&D investment is subject to high adjustment costs. These features suggest that dynamic panel data models are the most appropriate modelling framework, while static models should control for serial correlation. In both cases, estimation results may differ substantially from simple static panel data models.

There are a number of ways how the research reported in this paper could be extended and taken further. For Japan, the model could be extended to look at the relationship between marketing expenditures and successful new drug innovations in Japan. Since marketing expenditures are the single largest cost component of Japanese drug firms, they might be much more responsive to changes in economic fortunes than R\&D expenditures. Also, it would be worthwhile re-estimating the data used in Grabowski and Vernon (2000), implementing the econometric refinements employed in this paper. This may have a significant impact on their results, possibly leading to qualitatively different conclusions. Finally, it would be interesting to conduct similar studies in other major drug markets, such as the European Union, as well as for more recent or longer periods of time. 


\section{ACKNOWLEDGEMENTS}

The authors would like to thank Mr. Mayo Mita, pharma analyst at Morgan Stanley Dean Witter Tokyo, for supplying the data used in this paper. Burcin Yurtoglu provided helpful comments. The usual caveats apply. 


\section{REFERENCES}

Acs Z.J., and D.B. Audretsch (1991) Innovation and Technological Change: An International Comparison. Basil Blackwell: Oxford.

Akerlof G.A. (1970) The market for "lemons": quality, uncertainty and the market mechanism, Quarterly Journal of Economics, 84, 488-500.

Arellano M., and S.R. Bond (1991) Some tests of specification for panel data: Monte Carlo evidence and an application to employment equations, Review of Economic Studies, 58, 277-297.

Baltagi B.H., and P.X. Wu (1999) Unequally spaced panel data regressions with AR(1) disturbances, Econometric Theory, 15, 814-823.

Blundell R.W., and S.R. Bond (1998) Initial conditions and moment restrictions in dynamic panel data models, Journal of Econometrics, 87, 115-143.

Bond S., D. Harhoff, and J. Van Reenen (2003) Investment, R\&D, and financial constraints in Britain and Germany. Centre for Economic Performance, LSE, CEP Discussion Paper, 0595.

Bond S.R. (2002) Dynamic panel data models: a guide to micro data methods and practice, Portuguese Economic Journal, 1, 141-162 (also available as cemmap Working Paper, CWP09/02).

Cohen W.M. (1995) Empirical studies of innovative activity, in P. Stoneman (Ed.), Handbook of the Economics of Innovation and Technological Change. Blackwell: Oxford, pp. 182-264.

Cohen W.M., and D. Levinthal (1990) Absorptive capacity: A new perspective on learning and innovation, Administrative Science Quarterly, 35, 128-152 (reprinted in Mansfield E. and Mansfield E. (eds.) (1993), The Economics of Technical Change, Edward Elgar: Aldershot, UK and Brookfield, US, 458-85).

Cohen W.M., and D. Levinthal (1989) Innovation and learning: The two faces of R\&D, Economic Journal, 99, 569-596 (reprinted in Mansfield E. and Mansfield E. (eds.) (1993), The Economics of Technical Change, Edward Elgar: Aldershot, UK and Brookfield, US, 458-85).

Grabowski H.G., and J.M. Vernon (2000) The determinants of pharmaceutical research and development expenditures, Journal of Evolutionary Economics, 10, 201-215.

Grabowski H.G., and J.M. Vernon (1994) Return to R\&D in new drug introductions in the 80's, Journal of Health Economics, 13, 383-406.

Griliches Z., and J. Mairesse (1990) R\&D and productivity growth: Comparing Japanese and US manufacturing firms, in C. Hulten (Ed.), Productivity Growth in Japan and the United States. Chicago, pp. 317-348.

Gugler K., D.C. Mueller, and B.B. Yurtoglu (2003) Marginal q, Tobin's q, cash flow and investment, Southern Economic Journal, 70, 512-531.

Hall B.H. (2002) The financing of research and development, Oxford Review of Economic Policy, 18, 35-51.

Hall B.H. (1992) Investment and research and development at the firm level: Does the source of financing matter. NBER Working paper, no. 4096, NBER: Cambridge, MA.

Hall B.H., J. Mairesse, L. Branstetter, and B. Crépon (1999) Does cash flow cause investment and R\&D: An exploration using panel data for French, Japanese and United State firms in the scientific sector, in D. Audretsch and R.R. Thurik (Eds.), Innovation, Industry Evolution and Employment. Cambridge University Press: Cambridge.

Henderson R.M., and I. Cockburn (1996) Scale, scope and spillovers: The determinants of research productivity in drug discovery, RAND Journal of Economics, 27, 32-59. 
Hisashige A. (1997) Healthcare technology assessment and the challenge to pharmaeconomics in Japan, PharmacoEconomics, 11, 319-333.

Hoshi T., and A.K. Kashyap (2001) Corporate Financing and Governance in Japan. MIT Press: Cambridge, MA.

Hoshi T., A. Kashyap, and D. Scharfstein (1991) Corporate structure, liquidity and investment: Evidence from Japanese panel data, Quarterly Journal of Economics, 100, 33-60.

Hubbard R.G. (1998) Capital-market imperfections and investment, Journal of Economic Literature, 26, 193-225.

Huttin C. (1995) The Japanese drug price policy: A new dynamic on price competition, Journal of Research in Pharmaceutical Economics, 4, 21-34.

IMS HEALTH (2003) IMS World Review 2003. Fairfield, CT.

Koseisho [Ministry of Health and Welfare] (1996) Kazoku to shakai hosho- kazoku no shakaiteki shien no tame ni [Family and Social Insurance]. Tokyo.

McLellan M. (1997) A turning point in Japanese sales promotion, Scrip Magazine, 10, 25-27.

Miarka T. (1999) The recent economic role of bank-firm relationships in Japan. WZB Discussion Paper, FS IV 99-36.

Morgan Stanley Dean Witter (1998) Japan Investment Research: Japan Pharmaceuticals. Tokyo.

Mulkay B., B.H. Hall, and J. Mairesse (2001) Investment and R\&D in France and in the United State, in D. Bundesbank (Ed.), Investing Today for the World of Tomorrow. Springer: Berlin, Heidelberg and New York.

OECD (2001) Science, Technology and Industry Scoreboard 2001. OECD: Paris.

Oliver A.J., N. Ikegami, and S. Ikeda (1997) Japan's aging population -- Implications for healthcare, PharmacoEconomics, 11, 306-318.

PhRMA (2003) Industry Profile. Washington, D.C.

PhRMA (1999) Industry Profile. Washington, D.C.

Reich M.R. (1990) Why the Japanese don't export more pharmaceuticals: Health policy as industrial policy, California Management Review, 32, 124-150.

Scherer F.M., D. Harhoff, and J. Kukies (2000) Uncertainty and the size distribution of rewards from innovation, Journal of Evolutionary Economics, 10, 175-200.

Sharp M., and P. Patel (1997) Europe's pharmaceutical industry: an innovation profile, in A. Arundel and R. Garrelfs (Eds.), Innovation Measurement and Policies. European Commission: Luxembourg.

Silverberg G., and B. Verspagen (2005) The size distribution of innovations revisited: an application of extreme value statistics to citation and value measures of patent significance, Journal of Econometrics (forthcoming).

Thomas L.G. (2001) The Japanese Pharmaceutical Industry: The New Drug Law and the Failure of Industrial Policy. Edward Elgar: Cheltenham, UK and Northampton, MA, US.

Tylecote A. (1994) Financial systems and innovation, in M. Dodgson and R. Rothwell (Eds.), The Handbook of Industrial Innovation. Edward Elgar: Aldershot, UK and Brookfield, US, pp. 259-267. 


\section{THE UNU-MERIT WORKING PAPER SERIES}

\# 2006-001 A Knowledge Economy Paradigm and its Consequences by Luc Soete.

\# 2006-002 Public-Private Sector Partnerships in an Agricultural System of Innovation: Concepts and Challenges by Andy Hall.

\# 2006-003 Capacity Development for Agricultural Biotechnology in Developing Countries: Concepts, Contexts, Case Studies and Operational Challenges of a Systems Perspective by Andy Hall and Jeroen Dijkman.

\# 2006-004 Technological Capabilities with Different Degree of Coherence: A Comparative Study of Domestic-Oriented vs. Export-Driven Bulgarian Software Companies by Rossitza Rousseva.

\# 2006-005 Small Islands, New Technologies and Globalization: A Case of ICT adoption by SMEs in Mauritius by Kaushalesh Lal and Aveeraj Sharma Peedoly.

\# 2006-006 Beyond Unobserved Heterogeneity in Computer Wage Premiums; and Data on Computer use in Germany, 1997-2001. Double paper by Joan Muysken, Sybrand Schim van der Loeff and Valeria Cheshko.

\# 2006-007 Learning in Local Systems and Global Links: The Otigba Computer Hardware Cluster in Nigeria by Banji Oyelaran-Oyeyinka

\# 2006-008 Breaking the Fence: Patent Rights and Biomedical Innovation in "Technology Followers" by Padmashree Gehl Sampath

\# 2006-009 Taxation and Technolgoy Adoption: A Hotelling Approach by Ben Kriechel and Thomas Ziesemer

\# 2006-010 Foreign Direct Investment and Technology Spillovers: Evidence from the Indian Manufacturing Sector by Subash Sasidharan

\# 2006-011 Persistence of Innovation in Dutch Manufacturing: Is it Spurious? by Wladimir Raymond, Pierre Mohnen, Franz Palm and Sybrand Schim van der Loeff

\# 2006-012 Random walks and cointegration relationships in international parity conditions between Germany and USA of the post Bretton-Woods period by Franco Bevilacqua

\# 2006-013 On the Persistence of Inequality in the Distribution of Personal Abilities and Income by Adriaan van Zon and Hannah Kiiver

\# 2006-014 Foreign Direct Investment, Firm-Level Capabilities and Human Capital Development: Evidence from Kenyan Manufacturing Industry by Geoffrey Gachinol

\# 2006-015 The Determinants of Pharmaceutical R\&D Expenditures: Evidence from Japan by Jörg C. Mahlich and Thomas Roediger-Schluga 